\title{
Slope water, Gulf Stream, and seasonal influences on southern Mid-Atlantic Bight circulation during the fall-winter transition
}

\author{
L. L. Rasmussen, ${ }^{1}$ G. Gawarkiewicz, and W. B. Owens \\ Woods Hole Oceanographic Institution, Woods Hole, Massachusetts, USA
}

M. S. Lozier
Duke University, Durham, North Carolina, USA
Received 5 February 2004; revised 25 August 2004; accepted 22 December 2004; published 16 February 2005.

[1] Observations from autumn 2000 near the shelfbreak front in the Middle Atlantic Bight are used to describe the transition from stratified summer conditions to well-mixed winter conditions over the shelf. During the observational period, the front differed dramatically from climatological conditions, with buoyant Gulf Stream water found shoreward over the subsurface shelfbreak front. Water mass analysis shows a large number of separate water masses with shelf, slope, and Gulf Stream origins. The coolest shelf water was located at the shelfbreak and may be related to "cold pool" water masses observed to the north during summer. Shoreward of this shelfbreak water mass, a mid-shelf front was present which intersected the bottom at the $50-\mathrm{m}$ isobath. High-volume transports were associated with both the shelfbreak and mid-shelf fronts. Transport estimates from the cross-shelf sections were approximately 1 Sverdrup, which is large relative to previous estimates of shelf transport. The foot of the front was near the 130-m isobath, much deeper than the climatological position near the 75-m isobath; however, this is consistent with a recent theory relating the magnitude of alongshelf transport to the depth at which the front intersects the bottom.

Citation: Rasmussen, L. L., G. Gawarkiewicz, W. B. Owens, and M. S. Lozier (2005), Slope water, Gulf Stream, and seasonal influences on southern Mid-Atlantic Bight circulation during the fall-winter transition, J. Geophys. Res., 110, C02009, doi:10.1029/2004JC002311.

\section{Methods}

[2] Data were collected from the R/V Cape Hatteras in the MAB between Delaware Bay and Chesapeake Bay, approximately $300 \mathrm{~km}$ north of Cape Hatteras, on 35 November 2000. Four 60- to $80-\mathrm{km}$ cross-shelf sections were occupied, centered on the shelfbreak, as well as additional stations near the $1000-\mathrm{m}$ isobath (Figure 1). Conductivity, temperature, and depth were measured using a SeaBird $911+$ CTD at station intervals of $5 \mathrm{~km}$ in the cross-shelf direction from approximately the $40-\mathrm{m}$ isobath to the $1500-\mathrm{m}$ isobath. Velocity was measured using an RDI 150-kHz ADCP with 8-m bin size, 8-m vertical averaging, and an ensemble length of $3 \mathrm{~min}$. One of the four ADCP beams was not working, so the entire data set uses three-beam solutions. No bottom tracking was available for calibration. In this region the largest tidal component is the M2 tide $(2.4 \mathrm{~cm} / \mathrm{s}$ at station $\mathrm{WQ}$, $37.92^{\circ} \mathrm{N}, 74.93^{\circ} \mathrm{W}$ ). Since this speed is small relative to

\footnotetext{
${ }^{1}$ Now at Scripps Institution of Oceanography, University of California, San Diego, California, USA.

Copyright 2005 by the American Geophysical Union. 0148-0227/05/2004JC002311\$09.00
}

measured current velocities of over $60 \mathrm{~cm} / \mathrm{s}$, the ADCP data were not detided [Moody et al., 1984]. Wind measurements were taken from the nearest National Data Buoy Center buoy, NDBC 44009, located $26 \mathrm{nmi}$ southeast of Cape May, New Jersey (approximately $30 \mathrm{~km}$ north-northwest of the study area). Winds were predominantly from the northwest preceding and during the survey. For the 4 days prior to the cruise (30 October to 2 November), the average wind speed was $10.0 \mathrm{~m} / \mathrm{s}$ from $330^{\circ}$. During the cruise (3-6 November), the average wind speed was $5.8 \mathrm{~m} / \mathrm{s}$ from $320^{\circ}$. As will be seen in the next section, the onshore Ekman transport affected the distribution of water masses within the front.

[3] The coordinate system we will use for presenting the hydrographic sections is rotated to be aligned with the $100-\mathrm{m}$ isobath, and cross-shelf distance is also taken from this isobath. In the rotated coordinate system, $\mathrm{u}$ is positive to the northeast and $\mathrm{v}$ is positive to the northwest.

\section{Frontal Structure}

[4] Autumn is a particularly complicated time period over the MAB shelf, as it is a transition from the highly stratified summer conditions to the well-mixed conditions that prevail over the shelf in winter. Lentz et al. [2003] have shown that 


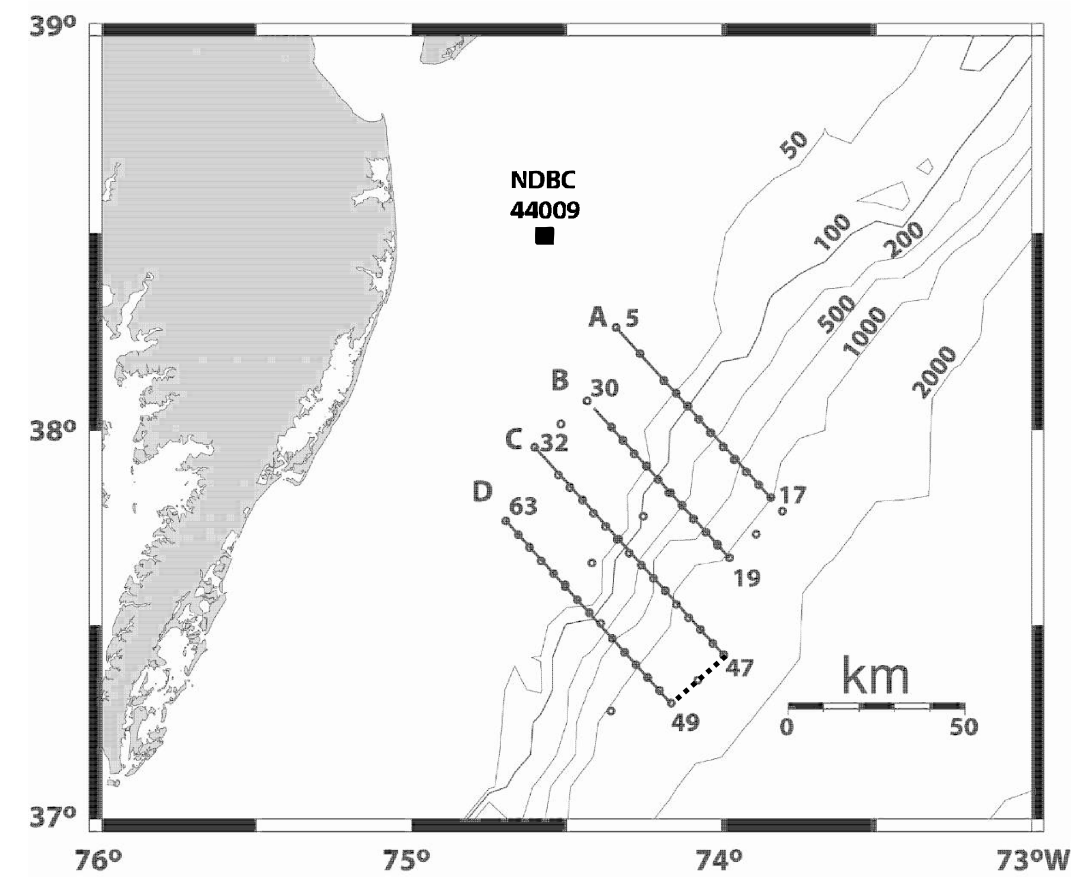

Figure 1. Cruise track and station locations for R/V Cape Hatteras cruise 2300, 2-6 November 2000.

this transition occurs primarily through storms with associated high wind stresses, as suggested earlier by Beardsley et al. [1985]. Thus, autumn conditions are likely to be poorly represented by climatology.

[5] Nonetheless, climatological temperature and salinity fields from this season (S. Lentz, personal communication, 2003) show several important features in this region (Figure 2). First, the seasonal thermocline is still evident, with surface to bottom temperature differences ranging between $2^{\circ}$ and $6^{\circ} \mathrm{C}$ across the section. Second, there is a distinct temperature minimum of $12^{\circ} \mathrm{C}$ over the outer shelf between the 40- and 80-m isobaths, presumably the remnants of a winter cold pool.

[6] Third, the strongest cross-shelf salinity gradient (where the salinity increases from 33.5 to $35 \mathrm{psu}$ ) is between the 60 - and $100-\mathrm{m}$ isobaths, in the vicinity of the shelfbreak. (Note that in the averaged hydrography the shelfbreak is at the $60-\mathrm{m}$ isobath. The averaging included all NODC data collected between September and November over the shelf between Delaware and Chesapeake Bays.)

[7] Another climatology, one focused more directly on the shelfbreak [Linder and Gawarkiewicz, 1998], shows the strongest cross-shelf density gradients near the shelfbreak. During the autumn, the Linder and Gawarkiewicz [1998] climatology shows the foot of the front intersecting the bottom at the 75-m isobath off New Jersey. The foot of the front is the point at which the cross-shelf gradients are a maximum along the bottom. It is thus the point at which the frontal isopycnals intersect the bottom. For the shelfbreak front, the location of the foot of the front is usually independent of the choice of temperature, salinity, or density, as the gradients of these properties are usually coincident near the bottom. Additionally, using these climatological fields the authors determined that the autumn geostrophic currents were $0.18 \mathrm{~m} \mathrm{~s}^{-1}$ to the southwest.
[8] The cross-shelf sections from our survey differed in a number of ways from the climatological structure. We will now describe the water masses, mixed layer structure, and response of the front to wind forcing. Water mass distributions from this cruise are complicated. As Churchill et al. [1993] have shown, the northward transport of Gulf Stream and South Atlantic Bight shelf water masses, coupled with the southward transport of Middle Atlantic Bight shelf and slope water masses, leads to complex $\mathrm{T} / \mathrm{S}$ characteristics. This is apparent in the $\mathrm{T} / \mathrm{S}$ diagrams from the northernmost (A) and southernmost (D) of the four cross-shelf transects (Figure 3). In section $\mathrm{A}$, there is a notable intrusion of warm saline slope water with a maximum temperature of $17^{\circ} \mathrm{C}$ and a maximum salinity of $35 \mathrm{psu}$. The density of this intrusion is 25.2 $\sigma_{\theta}$, which is less dense than the coolest shelf water $\left(12^{\circ} \mathrm{C}\right.$, $\left.26.2 \sigma_{\theta}\right)$. The intrusion of slope water is also present in section D along with Gulf Stream water with temperatures greater than $20^{\circ} \mathrm{C}$. Note that the coolest shelf water has a salinity of $34 \mathrm{psu}$, and thus one might expect from the climatology that this would be cold pool water concentrated near the shelfbreak. Temperatures and salinity across each transect are shown in Figures 4-7.

[9] These two sections have some features in common with the climatology, but also contain several striking differences (Figures 4 and 7). First, the frontal structure of the sections is significantly different. The synoptic sections exhibit enhanced salinity and density gradients near the shelfbreak, as seen in the climatology, but, additionally, enhanced salinity and density gradients are noted on the shelf, near the 50-m isobath. Such enhancement is only barely apparent in the climatological fields. Also, the sections contain a temperature minimum near the shelfbreak of $12^{\circ} \mathrm{C}$, with warmer, relatively isothermal water shoreward of this offshore minimum. 

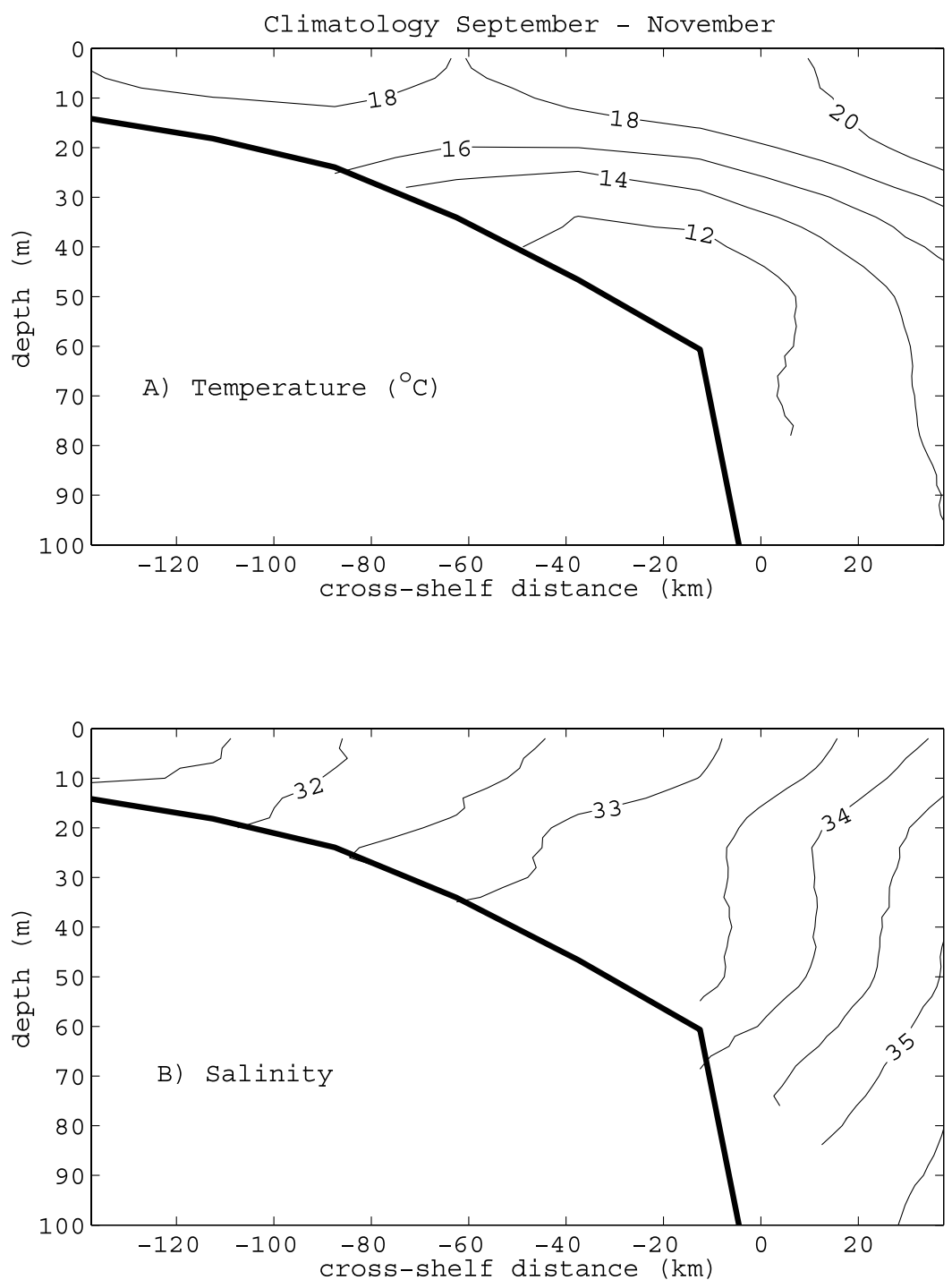

Figure 2. Climatology of Mid-Atlantic Bight between Delaware and Chesapeake Bay. (a) Temperature, and (b) salinity (S. Lentz, unpublished data, 2003).

[10] Another departure from the climatology is the depth of the bottom intersection of the foot of the shelfbreak front. In sections $\mathrm{A}$ and $\mathrm{D}$, this occurs at the $140-$ and $120-\mathrm{m}$ isobaths, respectively. This is substantially deeper than the isobath $(75 \mathrm{~m})$ of the foot of the front from the climatology. In section 5, we will show how the anomalously deep foot of the front is related to the large transport for this current through the theory of Yankovsky and Chapman [1997].

[11] Second, there are striking differences in the thermohaline structure of the surface mixed layer relative to the climatology. In the synoptic sections, warm saline slope water overlies the temperature minimum at the shelfbreak. Note that in section A, the surface water has a salinity of $35.0 \mathrm{psu}$ and a temperature of $17^{\circ} \mathrm{C}$. This is consistent with the properties of the slope intrusion from Figure 3. Sections B and $\mathrm{C}$ (Figures 5 and 6 , respectively) show significant shoreward penetration of surface slope water relative to the offshore edge of the cold pool. In section D, however, there is not as much onshore penetration, and the surface slope water only appears near the offshore edge of the section.
[12] Local winds are the likely cause of some of the surface slope water movement over the cool shelf water near the shelfbreak. For the 2 days prior to the cruise (12 November) the mean wind speed was $12 \mathrm{~m} / \mathrm{s}$ from $327^{\circ}$ and decreased in magnitude over the course of the cruise, with a mean of $4.3 \mathrm{~m} / \mathrm{s}$ from $259^{\circ}$ over 5-6 November. The onshore Ekman transport could have driven surface slope water onto the shelf during the first few days of November. Assuming a two-layer flow [e.g., Fong, 1998], the distance of an onshore excursion of slope water is given by

$$
L_{x}=\int_{t_{0}}^{t_{1}} \frac{\tau_{y}}{\rho h f} d t,
$$

where $h$ is the mixed layer thickness, $\tau_{y}$ is the northward wind stress, $\rho$ is the layer density, $L_{x}$ is the eastward distance the surface layer is advected by the Ekman transport, and $f$ is the Coriolis parameter. Figure 8 shows the westward distance the surface slope water would travel if exposed to the northward component of wind 

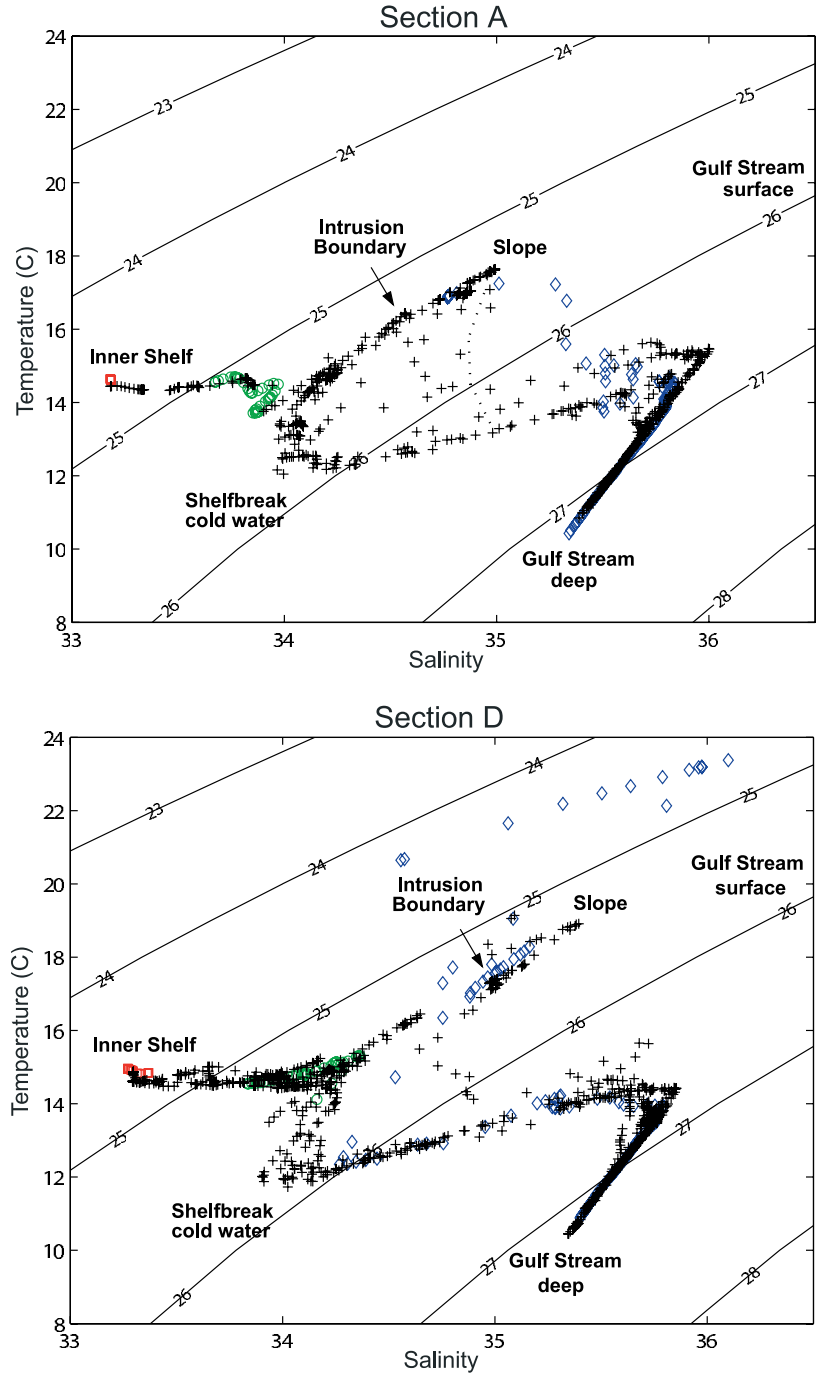

Figure 3. T-S diagrams for sections A and D. Red squares, inshore station; blue diamonds, offshore station; green circles, $100-\mathrm{m}$ isobath station. The light dashed line in Section A indicates a typical "inverted- $\mathrm{V}$ " property distribution for the MAB shelf. The blue diamonds along the 24.5 isopycnal in the bottom figure are from station 48 , offshore midway between sections C and D.

stress as observed at the nearest NDBC buoy. Three different choices of mixed layer depth are shown. By the midpoint of the cruise, 4 November, a surface mixed layer $30 \mathrm{~m}$ deep, similar to that observed in section B (Figure 5), would have moved westward approximately $25 \mathrm{~km}$, while the $50-\mathrm{m}$ surface mixed layers for sections A, $\mathrm{C}$, and D would have moved westward only about $15 \mathrm{~km}$. The onshore excursion distance is much smaller than the westward distance, reaching a maximum of only $5 \mathrm{~km}$ because the wind stress vector is primarily oriented across shelf. It is unclear whether the wind stress vector was oriented alongshelf at some time farther upstream or whether mesoscale advective processes account for the difference between the westward and cross-shelf components. South of the study area the isobaths are oriented primarily north-south and in this region the westward and cross-shelf excursions would be equivalent.
[13] In order for the slope water to be transported onshore above the cold pool water, the near-surface slope water must be less dense than the shelf water at the shelfbreak. Surface water from the slope or Gulf Stream, for example, would be expected to flow over the less saline outer shelf providing its temperature was high enough. Given shelf conditions of $15^{\circ} \mathrm{C}$ and $34.0 \mathrm{psu}$, a slope water mass with salinity $\leq 35.0$ would be less dense than shelf water if the slope water temperature is at least $3.5^{\circ} \mathrm{C}$ higher. Gulf Stream water with salinity of $36.0 \mathrm{psu}$ would require a $6.7^{\circ} \mathrm{C}$ temperature difference. AVHRR sea surface temperature imagery during this time period (Figure 9) contains Gulf Stream surface temperatures up to $27^{\circ} \mathrm{C}$ midstream, and $20^{\circ}-24^{\circ} \mathrm{C}$ in streamers expelled from meander crests, sufficiently buoyant to allow onshore penetration.

[14] In addition to the onshore movement of the surface mixed layer, the foot of the front is up to $10 \mathrm{~km}$ farther offshore and 50-70 $\mathrm{m}$ deeper than the climatological average. While the lower half of the front in most sections has a slope of $3-6 \times 10^{-3}$, similar to those reported by Gawarkiewicz et al. [1996] and Flagg and Beardsley [1978], the isohalines are nearly vertical in the upper $50-70 \mathrm{~m}$ of the water column. The horizontal gradients in salinity are particularly strong near the foot of the front directly over the shelfbreak at approximately 60-120 m depth. However, strong horizontal salinity gradients in the surface mixed layer are compensated by equally strong temperature gradients, thus creating weak density gradients at the surface. An interesting similarity between present observations and the Linder [1996] climatology is that the mean October-November 34.5 isohaline also exhibits a shoreward trend at mid-depth, raising the question of whether slopewater intrusions are common late fall events.

[15] The slopewater mass in the surface mixed layer extends along the entire alongshelf distance sampled during our cruise, as seen in horizontal maps of temperature, salinity, and density (Figure 10). A sharp front can be seen near the 100-m isobath, and Gulf Stream water in the southeast corner near the end of sections $\mathrm{C}$ and $\mathrm{D}$ is evident from the high salinities. At the southern end of the survey, shelf water extends farther offshore; the southern extent of the shelf water extending onto the slope was not resolved in our survey.

\subsection{Gulf Stream Influence}

[16] Gulf Stream water is found in a surface intrusion between transects $\mathrm{C}$ and $\mathrm{D}$ which overlies the deeper slope water mass (Figures 10 and 11). The vertical structure and temperature-salinity properties of this layer distinguish it from any of the other water masses in the survey, with salinity exceeding $36.0 \mathrm{psu}$ and temperature over $23^{\circ} \mathrm{C}$ at the core. This layer is visible in the T-S diagram (Figure 3, bottom) as the scattering of points along a 24.5 isopycnal at the top of the image, far removed from any other mixing line. The labels in the diagrams indicate the normal range of Gulf Stream temperature and salinity. Like the Gulf Stream water commonly found on the upper slope in the analysis by Churchill and Cornillon [1991], this $24.5 \sigma_{t}, 36$ psu water also has significantly lower density than the water mass that surrounds it. 

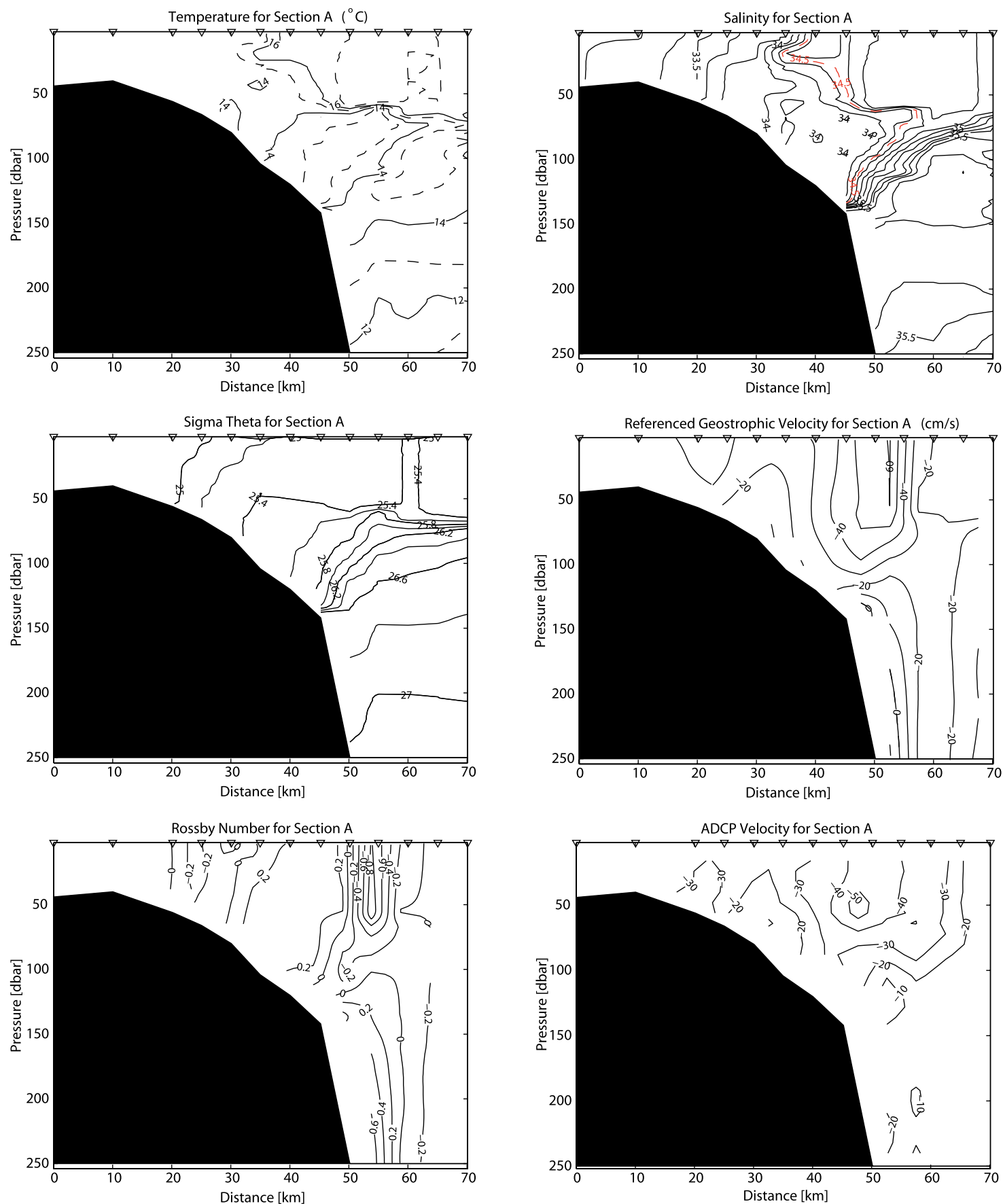

Figure 4. Section A. (top) Temperature, salinity; (middle) density, geostrophic velocity; (bottom) relative vorticity, normalized by $f(R o)$, ADCP velocity. Geostrophic velocity is initially estimated using zero bottom velocity; it is then corrected with the 250-m ADCP reference velocity, or the depth-averaged ADCP velocity for depths $<250 \mathrm{~m}$.

[17] The vertical extent of the Gulf Stream intrusion over the slope is approximately $25 \mathrm{~m}$ (Figure 11). Between sections $\mathrm{C}$ and $\mathrm{D}$, salinities were as high as $36.0 \mathrm{psu}$, and were larger than 35.4 psu over an alongslope distance of at least $20 \mathrm{~km}$. Within this alongslope section, there is a salinity minimum of 34.4 psu which is characteristic of water near the center of the shelfbreak front (see dashed salinity contours in Figures 4-7) and may be related to meandering of the frontal jet. The temperature was $14^{\circ} \mathrm{C}$. Near the surface, warm water $\left(22^{\circ} \mathrm{C}\right)$ extended over the upper $30 \mathrm{~m}$ of the water column, consistent with the mixed layer depths noted earlier in the cross-shelf transects.

[18] Sea surface temperature images during this time period also suggest the influence of Gulf Stream water on the outer shelf. The clearest image for this time period is from 25 October (Figure 9), in which there are numerous meanders with expelled Gulf Stream water extending toward the shelf as far as the outer stations of the survey transects. 

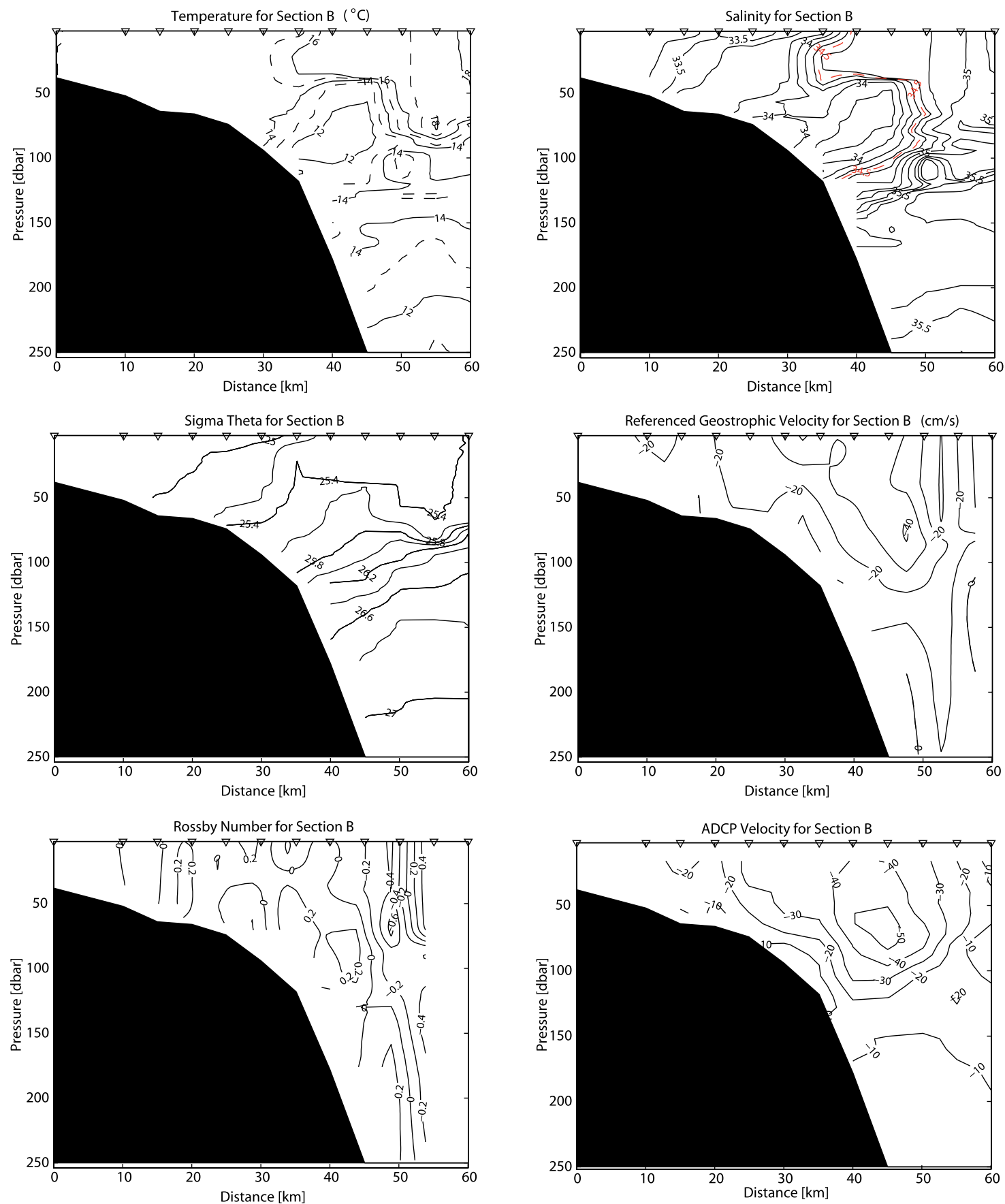

Figure 5. Section B. (top) Temperature, salinity; (middle) density, geostrophic velocity; (bottom) relative vorticity, normalized by $f(R o)$, ADCP velocity. Geostrophic velocity is initially estimated using zero bottom velocity; it is then corrected with the 250-m ADCP reference velocity, or the depth-averaged ADCP velocity for depths $<250 \mathrm{~m}$.

\subsection{Mid-Shelf Front}

[19] In addition to the shelfbreak front, a mid-shelf salinity and density front is present in all four transects. The foot of this front is near the $50-\mathrm{m}$ isobath, with surface outcrops $10-20 \mathrm{~km}$ farther offshore, near the 75-m isobath (see Figures 4-7). Ullman and Cornillon [1999] also observe mid-shelf fronts throughout the Mid-Atlantic Bight in winter AVHRR sea surface temperature imagery from 1985-1996. These temperature fronts appear around early January, and have surface outcroppings at the 50-m isobath. Prior to January a separate temperature front occurs in this region $40 \mathrm{~km}$ shoreward of the $50-\mathrm{m}$ isobath and persists until early February; the 50-m front appears to develop independently, however, and no migration of frontal features is apparent. Unlike these mid-shelf surface temperature fronts, the fronts observed during this survey are slightly farther offshore and do not have a corresponding temperature 

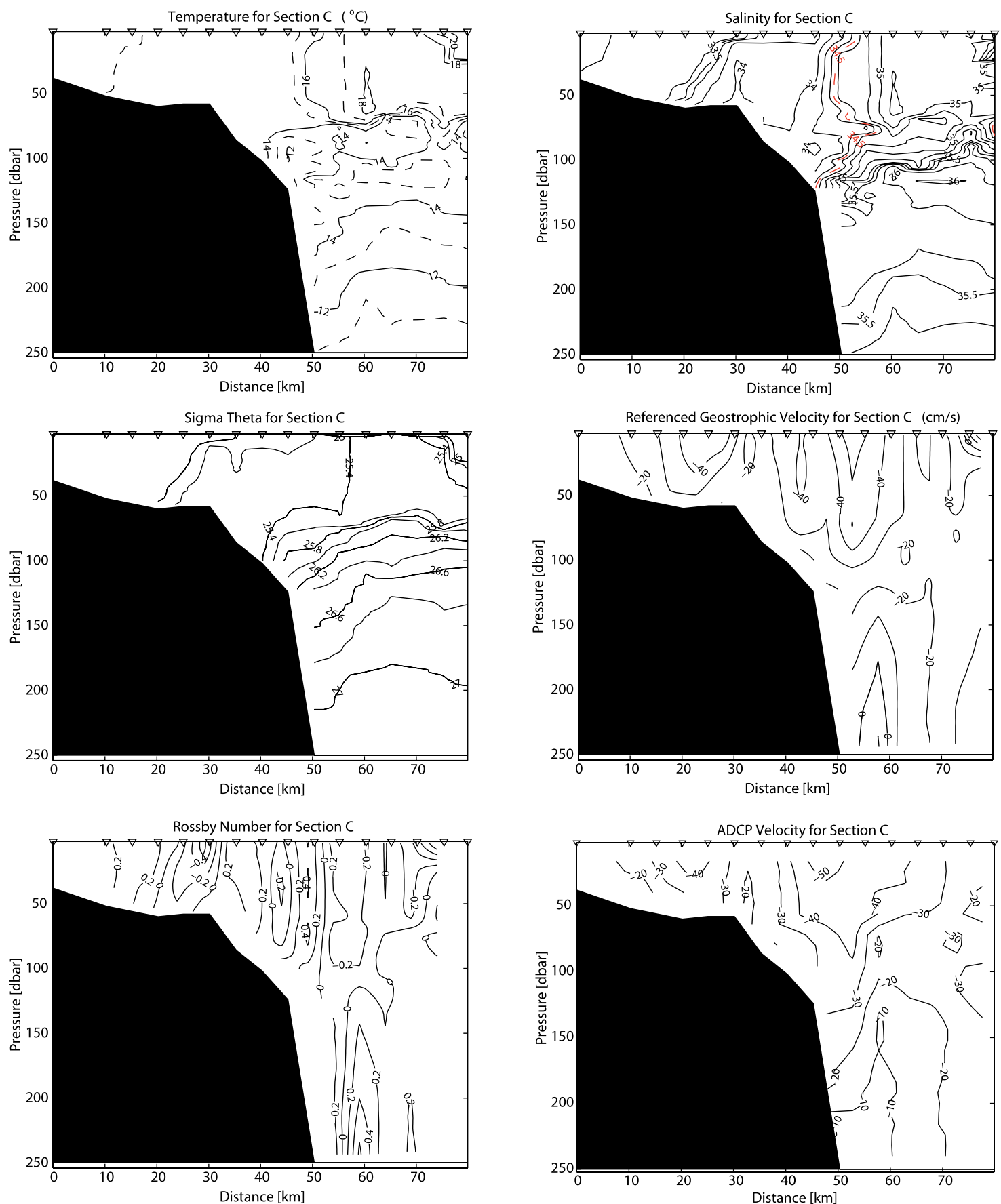

Figure 6. Section C. (top) Temperature, salinity; (middle) density, geostrophic velocity; (bottom) relative vorticity, normalized by $f(R o)$, ADCP velocity. Geostrophic velocity is initially estimated using zero bottom velocity; it is then corrected with the 250-m ADCP reference velocity, or the depth-averaged ADCP velocity for depths $<250 \mathrm{~m}$.

gradient, and thus would not be detectable in AVHRR imagery.

\section{Velocity Structure}

[20] Mean flow along the Mid-Atlantic Bight shelf is to the southwest and is primarily barotropic, with flow rates between 1 and $10 \mathrm{~cm} / \mathrm{s}$ [Beardsley et al., 1985]. However, density gradients normally present across the shelfbreak front result in a strong jet [Gawarkiewicz et al., 1996] in the same direction as the mean flow. In the climatology [Linder and Gawarkiewicz, 1998] the highest jet velocity occurs in summer and fall in our study area, with an average maximum velocity of approximately $0.18 \mathrm{~m} \mathrm{~s}^{-1}$ in October-November. The mean cross-shelf position of the jet at this time is $2 \mathrm{~km}$ offshore of the 100-m isobath, and mean jet width and depth are $25 \mathrm{~km}$ and $50 \mathrm{~m}$, respectively [Linder, 1996]. It should be noted 

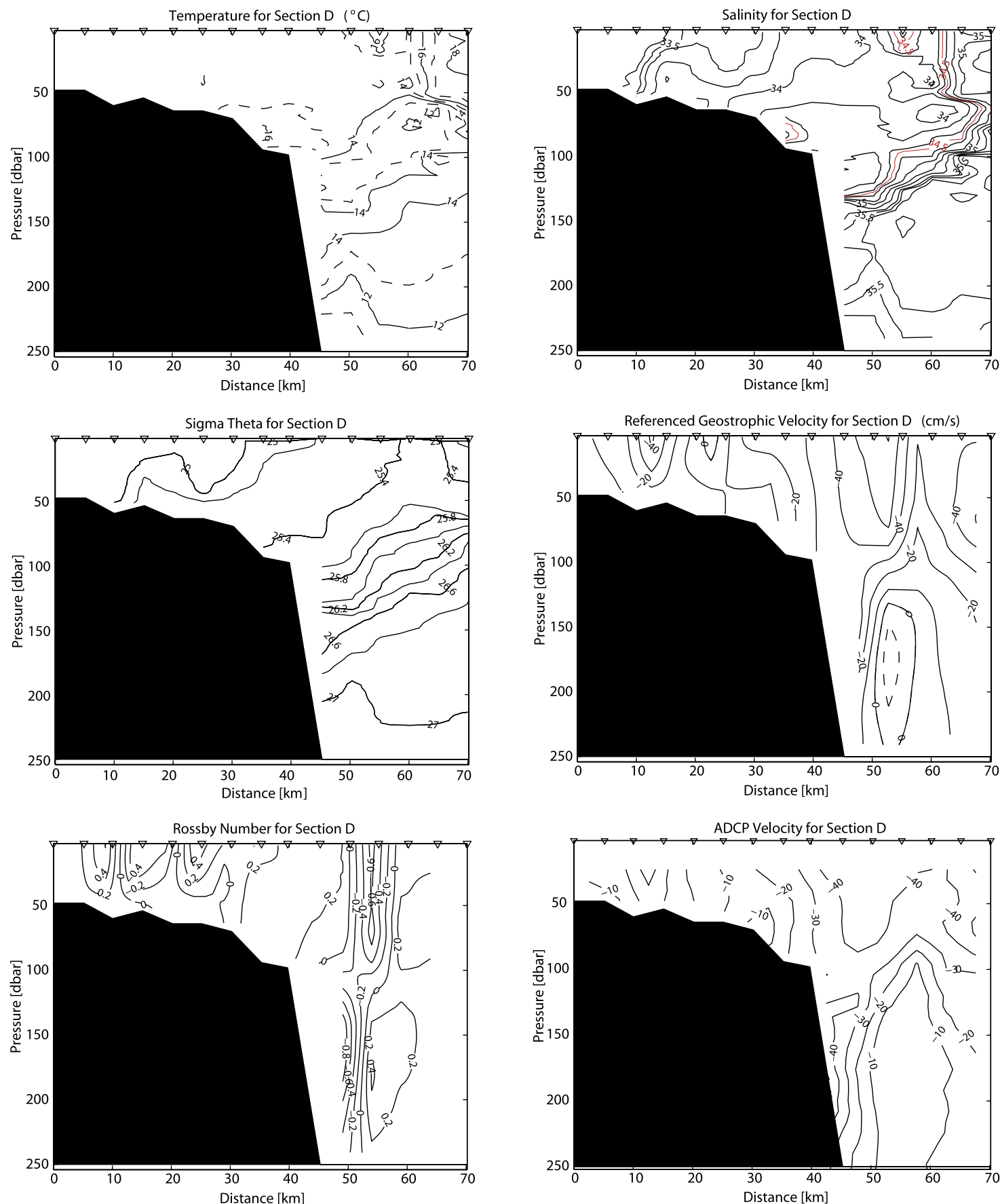

Figure 7. Section D. (top) Temperature, salinity; (middle) density, geostrophic velocity; (bottom) relative vorticity, normalized by $f(R o)$, ADCP velocity. Geostrophic velocity is initially estimated using zero bottom velocity; it is then corrected with the 250-m ADCP reference velocity, or the depth-averaged ADCP velocity for depths $<250 \mathrm{~m}$.

that differences between the climatological and individual measurements are partly due to smoothing effects of climatological averaging, which Linder [1996] estimates can alter dynamical results by a factor of $2-3$ (tending to decrease the magnitude of cross-shelf gradients and jet core velocity and increase jet width, for example). Smoothing will not affect the total volume transport, but it can significantly alter computed heat and salt flux values.
[21] Strong horizontal density gradients over the shelfbreak in our survey produce a shelfbreak jet. Velocities measured by the shipboard ADCP, averaged over the upper $70 \mathrm{~m}$ of the water column, show a strong jet with a velocity of approximately $0.60 \mathrm{~m} \mathrm{~s}^{-1}$ at the core. The jet flow is predominantly along isobaths until the southern transect (D), where there is a significant offshore component. Alongshelf flow was also computed using the thermal wind relation. The values were computed with zero bottom 


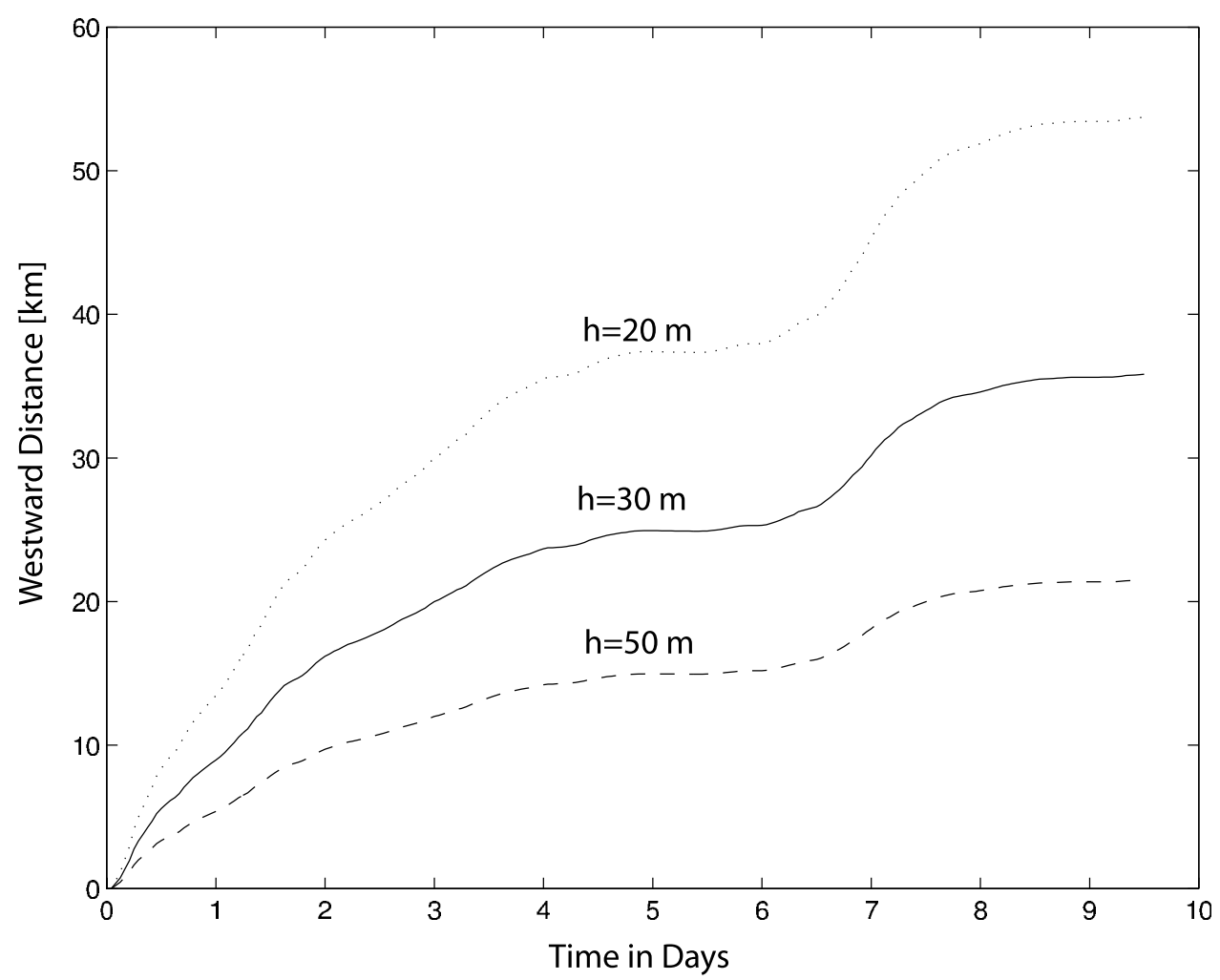

Figure 8. Westward excursion of surface slope water over the front after local wind forcing for mixed layers of $20 \mathrm{~m}, 30 \mathrm{~m}$, and $50 \mathrm{~m}$. Calculations are based on the north-south component of the wind from NDBC 44009 (see Figure 1). Days start at 30 October 0000 GMT.

velocity and adjusted for more realistic non-zero velocities by subtracting a bottom reference value. The ADCP velocities from $250 \mathrm{~m}$ were used as the bottom reference values; for water depths $<250 \mathrm{~m}$, the depth-averaged ADCP velocity was used as a reference. Next, the barotropic component of the flow was included by adding in the difference between the vertically integrated alongshelf component of the ADCP velocity and the vertically integrated geostrophic velocity. Figures 4-7 show geostrophic velocity for the four cross-shelf sections. The mean magnitude of the barotropic adjustment from the ADCP velocity, averaged over the four sections, is $13 \mathrm{~cm} / \mathrm{s}$ or approximately $20-25 \%$ of the maximum jet velocity (Figure 12).

[22] The maximum velocity computed in the core of the shelfbreak jet is over $60 \mathrm{~cm} / \mathrm{s}$ in transect $\mathrm{A}$, and ranges from 50 to $60 \mathrm{~cm} / \mathrm{s}$ on the other transects, consistent with the ADCP measurements. This velocity maximum is more than 3 times greater than that of the climatological jet. The synoptic jet is also observed to be quite deep (up to $100 \mathrm{~m}$ ) with a cross-shelf width of 20-30 km. It is in the high-velocity core of the jet below $50 \mathrm{~m}$ that we find the shelfbreak temperature minima; in transect $\mathrm{A}$ the velocity in the temperature minimum reaches $40-50 \mathrm{~cm} / \mathrm{s}$.

[23] Although the slope water intrusion in the surface mixed layer has moved the surface front well inshore of its mean climatological position $40 \mathrm{~km}$ beyond the $100-\mathrm{m}$ isobath [Linder and Gawarkiewicz, 1998], the jet cores from the four sections are displaced 10-20 km offshore of the $100-\mathrm{m}$ isobath, much farther offshore than the climatological mean ( $2 \mathrm{~km}$ offshore). Two features explain this offset between the surface thermal front and the velocity core.

[24] The large density gradients over the foot of the front (between 50-150 $\mathrm{m}$ depth) are in thermal wind balance with the strongly sheared velocity core. Within the mixed layer, $\mathrm{T}$ and $\mathrm{S}$ compensate so that horizontal density gradients near the surface thermal front are small, such that the velocity shear is also small near the surface.

[25] The presence of the strongest density gradients at the foot of the front and their apparent domination of jet velocity and position are consistent with the climatological fields [Linder and Gawarkiewicz, 1998]. One exception occurs in transect B. A related scenario can be found in the hydrographic survey farther south in the Mid-Atlantic Bight where Gawarkiewicz et al. [1996] note that a pycnocline salinity intrusion split the shelfbreak jet into two by creating two distinct horizontal density gradients, one above and one below the pycnocline. A similar process appears to be at work in transect B where horizontal density gradients are present both below the surface mixed layer and within the surface mixed layer, in agreement with two velocity maxima. The resulting jet is double-lobed, with one velocity maximum at the surface above the $100-\mathrm{m}$ isobath and one $20 \mathrm{~km}$ past the $100-\mathrm{m}$ isobath at $75 \mathrm{~m}$ depth. A similar split front and double-lobed jet are seen in transect $\mathrm{C}$, although here the surface density gradient is weaker than that at the foot of the front.

[26] Significant flow, with velocities of $30-40 \mathrm{~cm} / \mathrm{s}$, also occurs at the mid-shelf front throughout the survey area. 


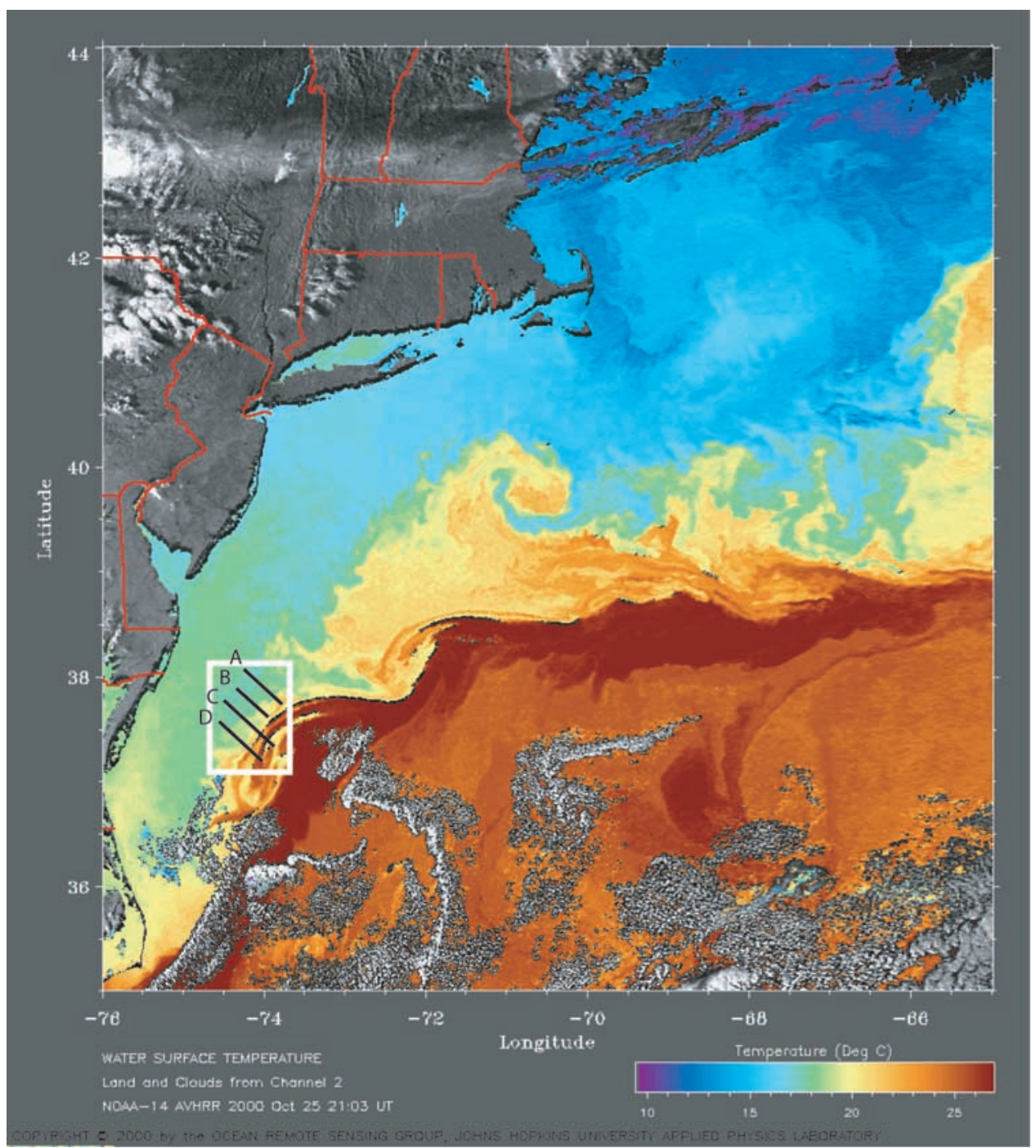

Figure 9. AVHRR sea surface temperature for Northern GS region, 25 October 2000. Study area and transect lines are indicated for reference only; image is from 1 week previous to survey dates. (From Johns Hopkins Applied Physics Laboratory, Ocean Sensing Group.)

Such flow rates rival those associated with a moderately strong shelfbreak jet. Note that the mid-shelf front is almost entirely a salinity front.

[27] The relative vorticity maxima within the front are larger than climatological values. The maximum values for both cyclonic and anticyclonic vorticities are 0.6 times the local Coriolis parameter. This is about 3 times larger than the value given by Linder and Gawarkiewicz [1998] from climatology, but is comparable to other synoptic measurements [Gawarkiewicz et al., 2004]. A recent stability analysis of the Mid-Atlantic Bight front [Lozier et al., 2002] suggests that the observed front would be unstable, with e-folding timescales for growth on the order of a day.

\section{Volume and Mass Transport}

[28] Volume and mass transport are controlled during our survey not only by the high jet velocity in the study area, but also by the vertical extent of the jet which is larger than previous observations. The total alongshelf transport is given in Table 1. The volume transport is calculated in a variety of ways: for the shelfbreak jet, for the barotropic component of the shelfbreak jet alone, for the mid-shelf jet when present, and for the entire shelf section that was sampled. The vertical boundary of the jet is defined by the depth of the central isopycnal at the foot of the density front; this ranges from 120 to $134 \mathrm{~m}$. Horizontal boundaries are defined by the distance at which velocity drops below $20 \mathrm{~cm} / \mathrm{s}$, or by the local velocity minimum in cases where the shelfbreak and midshelf jets overlap. Along with each "whole section" estimate is the actual shelf width used in the calculation, which varies depending on the cross-shelf data $\operatorname{set}(\mathrm{s})$ used.

[29] For comparison, estimates of volume transport from other studies of the Mid-Atlantic Bight are shown [Burrage and Garvine, 1988; Biscaye et al., 1994; Beardsley et al., 1985; Ramp et al., 1988; Linder and Gawarkiewicz, 1998; Gawarkiewicz et al., 1996; Schlitz 

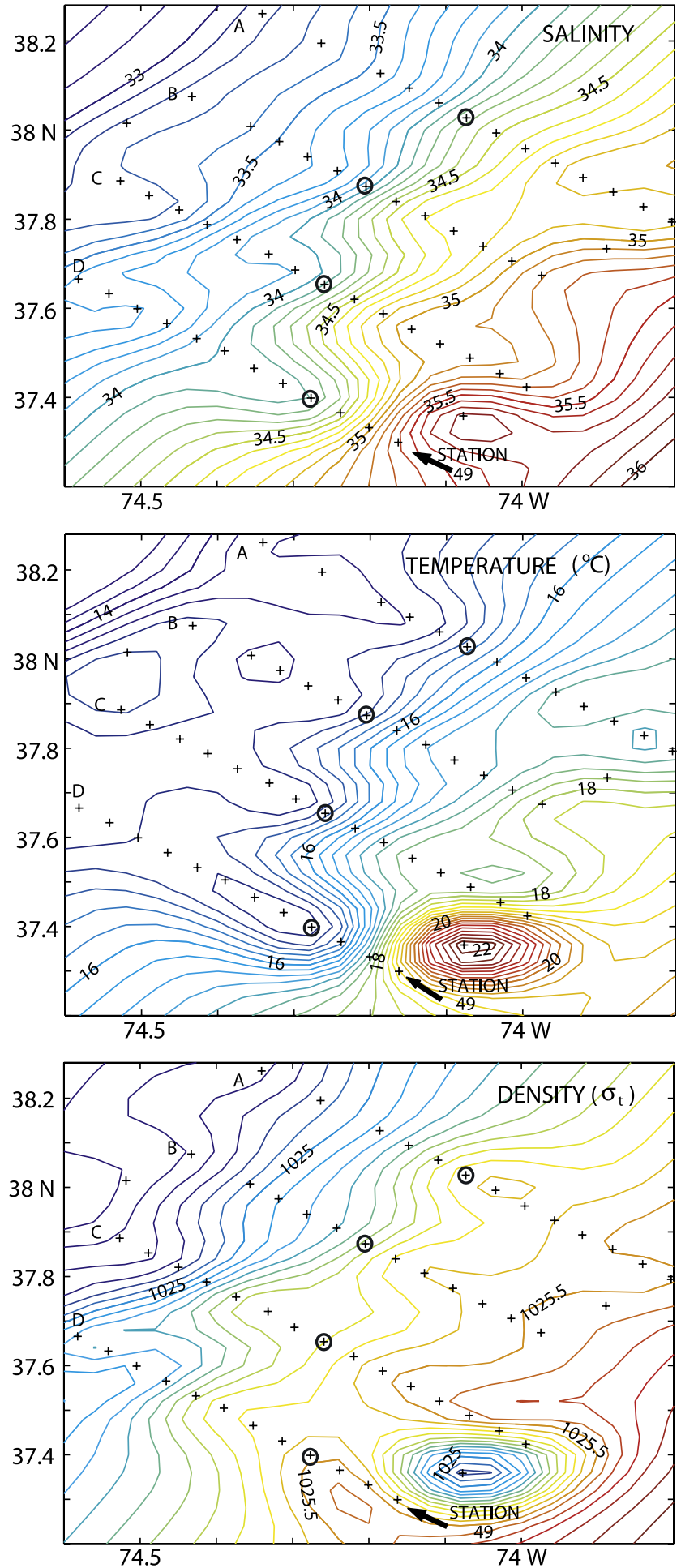

Figure 10. Horizontal contours at $25 \mathrm{~m}$ depth for (a) salinity, (b) temperature, and (c) density. CTD stations are marked with crosses, and those nearest the $100-\mathrm{m}$ isobath are circled.

et al., 2001]. The 0.7-1.3 Sv transport within the shelfbreak jet in the present study is comparable or far exceeds other estimates for whole shelf transport. Transport within the shelfbreak jet accounts for $61-77 \%$ of the total transport over each section. Volume transport within the mid-shelf jet is lower, but comparable to previous estimates of transport over the entire shelf. In the transport estimates from other studies, those derived from shelf transects that resolve the shelfbreak jet are considerably higher than those based on more widely spaced moorings or sampling stations. The increased transport seen here cannot be explained solely by the inclusion of the barotropic velocities since the barotropic transport represents only approximately $20 \%$ of the total.

[30] The large differences in transport between the sections we observed are largely due to differences in the total cross-shelf distance of the separate cross-shelf sections. Note that some of the differences in total transport may also be due to the meandering of the shelfbreak jet across the offshore boundary of the sections. To make the sections more comparable, Table 2 presents transport for similar shelf widths, integrated to a full depth of $250 \mathrm{~m}$ (or bottom where the water column depth is less than $250 \mathrm{~m}$ ). The total
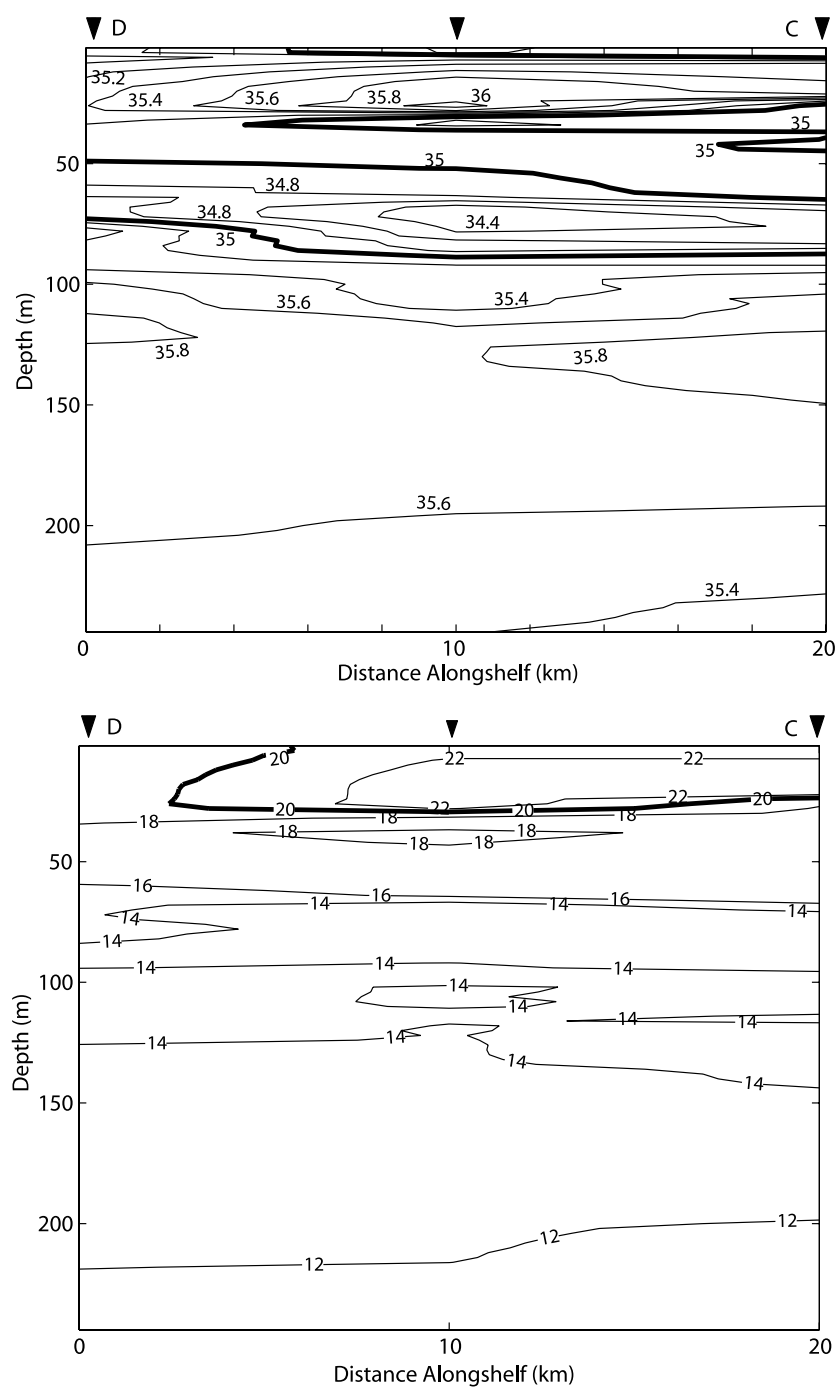

Figure 11. Vertical (top) salinity and (bottom) temperature contours for an alongshelf section between transects $\mathrm{C}$ and D. Orientation is looking shoreward, with transect $\mathrm{D}$ on the left. Location of the section is near the 1500-m isobath, and is shown on Figure 1 by the dashed line. 

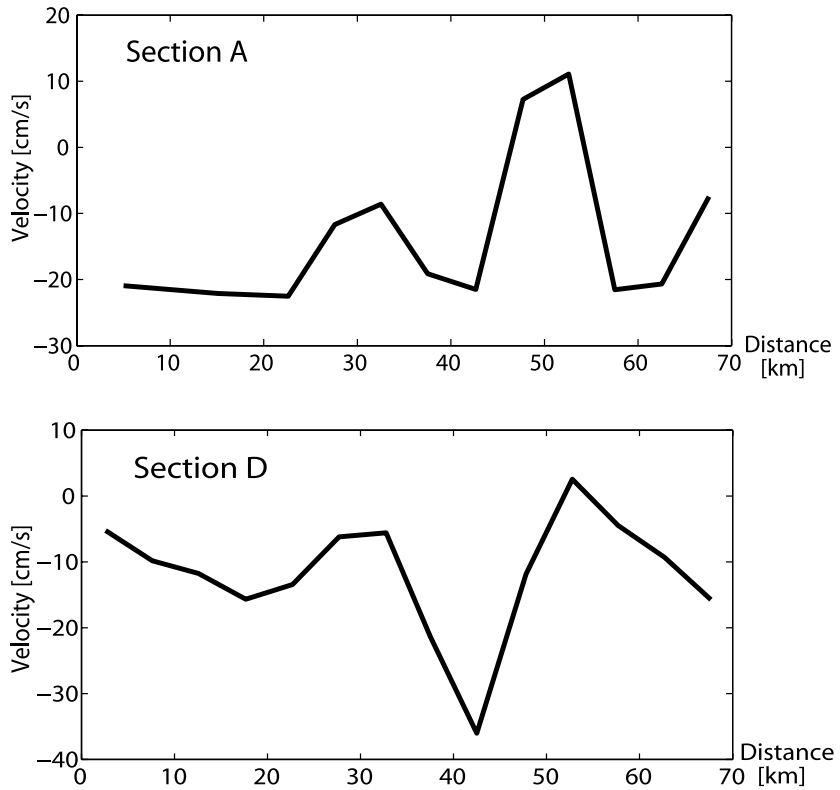

Figure 12. Barotropic velocity for cross-shelf sections (top) $\mathrm{A}$ and (bottom) D. The mean barotropic velocity magnitude over the four sections is $-13 \mathrm{~cm} / \mathrm{s}$.

transport in each section over the same width differs no more than $4-12 \%$ from the mean.

\section{Summary and Discussion}

[31] During a short survey in the late fall of 2000 in the southern Mid-Atlantic Bight shelfbreak region, we observed hydrographic features that may be important in the seasonal transition between fall and winter conditions. Gulf Stream and slope water interaction with the front strongly influenced the water mass and velocity structure at the shelfbreak.

[32] High-resolution sampling during the survey was crucial in identifying the complex structure of water masses in this region, as well as for resolving the property gradients that are associated with a complex velocity structure. The spatial scale for many of these features, some of which were subsurface, was relatively small $(5-10 \mathrm{~km})$. Mid-shelf gradients could have been missed or underestimated by coarser sampling, resulting in erroneous transport estimates. Resolving strong subsurface lateral gradients, as deep as $120-140 \mathrm{~m}$ and as narrow as $5 \mathrm{~km}$, was also critical in calculating the baroclinic flow and for accurately estimating the volume transports. These observations are relevant not only to understanding the local circulation, but also to understanding shelf circulation and transport along the length of the Mid-Atlantic Bight.

\subsection{Fall Transition Features}

[33] A cold shelfbreak water mass was observed in the area at the foot of the front with characteristics different from the "cold pool" found under the pycnocline on the New England shelf. The summertime cold pool has been understood to result from isolation of the winter mixed layer after summer stratification sets in. The features are assumed to dissipate with the onset of fall and winter wind-driven mixing. Houghton et al. [1982] found a positive association between duration of cold pool isolation in a region and the magnitude of the cross-sectional shelf area. They attribute this to the wide shelf area effectively insulating the cold pool on both sides, thereby minimizing the impact of heat transfer from the adjacent shallow shelf on one side and warm slope water on the other. Compared to the cross-sectional area of the rest of the Mid-Atlantic Bight, this survey area is in the lowest $25 \%$ of the range, with only the shelf to the south toward Cape Hatteras smaller; therefore one would not expect the local cold pool to persist into the fall. Houghton et al. also saw a southward migration of minimum bottom temperature on the shelf from the New York Bight toward Delaware Bay over the course of May-October, with a minimum bottom temperature of $9^{\circ}-10^{\circ \mathrm{C}}$ reaching the northern part of our study area by the end of October. Given the observed migration of cold pool water from the north, as well as the possibility of cold pool parcels becoming

Table 1. Volume Transport Comparison for Mid-Atlantic Bight Shelf/Slope ${ }^{\mathrm{a}}$

\begin{tabular}{|c|c|c|c|c|c|c|}
\hline Section & $\begin{array}{c}\text { Baroclinic } \\
\text { Jet }\end{array}$ & $\begin{array}{c}\text { Barotropic } \\
\text { Jet }\end{array}$ & $\begin{array}{c}\text { Jet } \\
\text { Width }\end{array}$ & $\begin{array}{c}\text { Mid-Shelf } \\
\text { Jet }\end{array}$ & $\begin{array}{l}\text { Whole } \\
\text { Section }\end{array}$ & $\begin{array}{c}\text { Section } \\
\text { Width }\end{array}$ \\
\hline A & $1.17 \mathrm{~Sv}$ & $0.22 \mathrm{~Sv}$ & $25 \mathrm{~km}$ & $\ldots$ & $1.51 \mathrm{~Sv}$ & $70 \mathrm{~km}^{\mathrm{b}}$ \\
\hline $\mathrm{B}$ & $0.69 \mathrm{~Sv}$ & $0.15 \mathrm{~Sv}$ & $20 \mathrm{~km}$ & $\ldots$ & $1.02 \mathrm{~Sv}$ & $60 \mathrm{~km}^{\mathrm{b}}$ \\
\hline $\mathrm{C}$ & $1.27 \mathrm{~Sv}$ & $0.31 \mathrm{~Sv}$ & $30 \mathrm{~km}$ & $0.39 \mathrm{~Sv}$ & $1.81 \mathrm{SV}$ & $80 \mathrm{~km}^{\mathrm{b}}$ \\
\hline $\mathrm{D}$ & $0.94 \mathrm{~Sv}$ & $0.46 \mathrm{~Sv}$ & $20 \mathrm{~km}$ & $0.14 \mathrm{~Sv}$ & $1.53 \mathrm{~Sv}$ & $70 \mathrm{~km}^{\mathrm{b}}$ \\
\hline Mean & $1.02 \mathrm{~Sv}$ & $0.29 \mathrm{~Sv}$ & $24 \mathrm{~km}$ & & & \\
\hline Voorhis et al. $[1976]^{\mathrm{c}}$ & & & & & $1 \mathrm{~Sv}$ & \\
\hline Beardsley et al. [1985] (M) ${ }^{\mathrm{d}}$ & & & & & $0.38 \mathrm{~Sv}$ & $70 \mathrm{~km}$ \\
\hline Ramp et al. [1988] (M) ${ }^{\mathrm{d}}$ & & & & & $0.22 \pm 0.4 \mathrm{~Sv}$ & $120 \mathrm{~km}$ \\
\hline Burrage and Garvine [1988] & & & & & $1.0 \mathrm{~Sv}$ & \\
\hline Biscaye et al. [1994] (M) & & & & & $0.19 \mathrm{~Sv}$ & \\
\hline Schlitz et al. [2001] (M) & & & & & $0.83 \pm 0.2 \mathrm{~Sv}$ & $70 \mathrm{~km}$ \\
\hline Gawarkiewicz et al. [1996] & $0.38 \mathrm{~Sv}$ & & $20 \mathrm{~km}$ & & & \\
\hline Linder and Gawarkiewicz [1998] & $0.16 \mathrm{~Sv}$ & & $30 \mathrm{~km}$ & & & \\
\hline
\end{tabular}

a(M) indicates estimates based on moored current meter observations; the remainder are based on geostrophic velocity from hydrographic sections

${ }^{\mathrm{b}}$ Transport is to depth of $100 \mathrm{~m}$ or bottom.

${ }^{\mathrm{c}}$ Voorhis et al. [1976] transport is calculated from geostrophic velocity between 100- and 1000-m isobaths (0.7 Sv), plus the NSFE [Beardsley et al., 1976] inner shelf transport.

${ }^{\mathrm{d}}$ Beardsley et al. [1976] and Ramp et al. [1988] calculations are from same NSFE data set; the former extends only to the shelfbreak, while the latter includes the upper slope and effects of warm core rings reversing normal flow. 
Table 2. Volume Transport for Shelf Sections of Similar Length, to Full Depth of $250 \mathrm{~m}$ or Bottom ${ }^{\mathrm{a}}$

\begin{tabular}{lccc}
\hline Section & $80 \mathrm{~km}$ & $70 \mathrm{~km}$ & $60 \mathrm{~km}$ \\
\hline A & $\ldots$ & $1.88 \mathrm{~Sv}$ & $1.46 \mathrm{~Sv}$ \\
B & $\ldots$ & $\ldots$ & $1.20 \mathrm{~Sv}$ \\
C & $2.61 \mathrm{~Sv}$ & $2.00 \mathrm{~Sv}$ & $1.46 \mathrm{~Sv}$ \\
D & $\cdots$ & $1.92 \mathrm{~Sv}$ & $1.30 \mathrm{~Sv}$ \\
Mean & & & $1.36 \mathrm{~Sv}$ \\
\hline
\end{tabular}

${ }^{\mathrm{a}}$ Larger lengths extend farther inshore.

detached and transported into the upper slope [Houghton and Marra, 1983], it seems reasonable to speculate that the shelfbreak temperature minima in our sections, with velocities of $30-50 \mathrm{~cm} / \mathrm{s}$, could be cold pool water originally from the northern MAB that has been entrained into the southward flowing shelfbreak jet. Traveling at this rate from the New York Bight, total transit time would be 6-10 days. One interesting result of having a cold water mass located directly over the foot of the salinity front is that the uniform temperature enables the salinity front to create a strong density gradient in the lower half of the water column; it is this density gradient that is primarily responsible for the strong shelfbreak jet observed during the survey.

[34] It is possible that the mid-shelf salinity fronts seen in this area are also a late fall seasonal feature. The fronts are within 10-20 km of the surface temperature fronts observed by Ullman and Cornillon [1999] that develop 2 months later, and may result from freshwater input from nearby bays. Since freshwater input would persist into winter, while the inner shelf cools, eventually the salinity fronts would develop a temperature gradient as well. It would be interesting to see the evolution of both surface temperature and salinity fronts simultaneously to determine if their development is related, or whether the salinity front remains isolated enough to maintain the density gradient associated with it. The density gradients associated with late fall midshelf salinity fronts are responsible for transport rates rivaling previous estimates of the entire shelf. If mid-shelf density fronts persist for long periods of time, their transport would be a significant contribution to annual shelf totals.

\subsection{Gulf Stream and Slope Influence on Thermohaline and Velocity Structures}

[35] A high-velocity shelfbreak jet with maximum flow rates of up to $60 \mathrm{~cm} / \mathrm{s}$ was observed during our autumnal survey. Data for climatological averaging in this region and season are scarce, so comparisons to a mean shelfbreak jet velocity can be tenuous; additionally, smoothing effects can make means of dynamical features difficult to interpret. Among the factors that could influence seasonal or interannual changes in jet position and velocity is remote forcing from the Gulf Stream, particularly in the southern MidAtlantic Bight where the Gulf Stream is proximate enough to have local as well as remote influence.

[36] The position of the north wall of the Gulf Stream was anomalously far north during this period. Between $71^{\circ} \mathrm{W}$ and $73^{\circ} \mathrm{W}$, the north wall of the Gulf Stream is approximately $0.25^{\circ}$ north of its mean position for the year 2000, and the 2000 mean is itself $0.5^{\circ}$ farther north than the climatological average over the period 19731997 (the second largest northward excursion since 1966) [Drinkwater et al., 1994; Page et al., 2001]. Sea surface temperature images from 2-7 November show that the Gulf Stream has moved slightly north during the 2 weeks after the 25 October image. Given the proximity and structure of the Gulf Stream in this region, it is likely that features such as the observed saline intrusion and overlying warm water mass are not isolated events and could have an important impact on shelfbreak processes on timescales of weeks to months. In particular, years in which there are significant northward excursions of the Gulf Stream could be crucial in affecting both the mean state of the shelfbreak front and exchange between the shelf and slope.

[37] Bane et al. [1988] analyzed the potential effect of Gulf Stream position relative to the shelf on shelfbreak current velocity. Average Gulf Stream position during 2000 was at its second most northerly position since 1966, and the location at the time of the survey was $50 \%$ farther north from its long-term mean than the annual average. Measuring from the Station B reference of Bane et al. [1988], approximately $100 \mathrm{~km}$ upstream of the shelfbreak jet from our transect A, the north wall of the Gulf Stream was $100 \mathrm{~km}$ away during the survey period. Bane et al. [1988] observed currents at Station B to be at their maximum velocity (30$40 \mathrm{~cm} / \mathrm{s}$ ) when the Gulf Stream position was within $150 \mathrm{~km}$, which would put our observations at the extreme of GS proximity and current velocity.

[38] In their study of mean shelfbreak jet dynamics, Fratantoni et al. [2001] note that the Bane relationship does not hold farther north in the Nantucket Shoals region. However, the Gulf Stream is approximately twice as far from the shelf there, compared to the southern Mid-Atlantic Bight. Farther south, Savidge and Bane [2001] found no correlation between Gulf Stream offshore position and current velocity, but they did see a strong correlation between Gulf Stream position and alongshelf velocity convergence, suggesting some relationship between Gulf Stream forcing and cross-shelf transport.

[39] Locally, AVHRR images from this time period show Gulf Stream meanders close to the shelf, with water ejected from meander crests reaching the study area. A high salinity and very warm water mass closely related to Gulf Stream surface water was observed in a thin layer overlying the slopewater intrusion in the southern part of the survey. The local surface salinity intrusions did not create density fronts that affected shelfbreak jet velocity, however, which is consistent with findings by Churchill and Cornillon [1991], but the proximity of the north wall of the Gulf Stream must be considered a factor in jet strength.

[40] Gulf Stream water in the surface mixed layer does have potential significance for shelf-slope exchange, since the buoyancy of this water mass relative to shelf water would allow it to penetrate the front and carry saline water onto the shelf. We note that Lentz [2003] identifies the majority of high-salinity intrusions as being either in the seasonal pycnocline or at the surface. Radiochemical properties that were measured during this survey also tie this water mass closely to water from the north wall of the Gulf Stream at Cape Hatteras.

\subsection{Relationship Between Transport and Thermohaline Structure}

[41] The transports calculated for the survey area are high, particularly for the southern Mid-Atlantic Bight where 
Table 3. Relationship Between Jet Transport, $T_{\text {jet }}$, Cross-Frontal Density Difference, and Depth of the Bottom Intersection of the Front $^{\mathrm{a}}$

\begin{tabular}{lcccc}
\hline Section & $T_{\text {jet }}, \mathrm{Sv}$ & $\Delta \rho$ & $h_{b}, \mathrm{~m}$ & $z$ (Actual), m \\
\hline A & 1.17 & 1.2 & 143 & 134 \\
B & 0.69 & 1.2 & 109 & 126 \\
C & 1.27 & 1.2 & 148 & 120 \\
D & 0.94 & 1.4 & 118 & 120 \\
Mean & 1.02 & 1.25 & 130 & 125 \\
\hline
\end{tabular}

a Bottom depth predicted by the Yankovsky and Chapman [1997] relation, $h_{b}$, is given as well as the actual depth of the foot of the front.

a portion of shelf flow is thought to be already detrained onto the slope. In particular, shelf transport rates are significantly higher than those calculated from lower resolution data sets that do not adequately resolve the shelfbreak jet. Transport within the jet in this survey accounts for $61-$ $77 \%$ of the total alongshelf transport.

[42] Are the anomalously large transports and depth of the foot of the front related? Yankovsky and Chapman [1997] developed a theory for buoyant coastal discharges which includes a length scale for the bottom depth of the plume attachment, $h_{b}$, in which the depth of the foot of the front is proportional to the transport and the density difference across the front:

$$
h_{b}=\left(2 L v_{i} h_{0} f / g^{\prime}\right)^{1 / 2}
$$

where $L v_{i} h_{0}$ is the transport within the plume, $f$ is the Coriolis parameter, and $g^{\prime}=g \Delta \rho / \rho_{0}$. We use this to predict the bottom depth of the front, given the jet transport and density difference, $\Delta \rho$. Table 3 shows that this relationship holds very well, particularly for the mean conditions seen during the survey.

[43] Mean jet transport over the four sections was $1.02 \mathrm{~Sv}$, with a mean density difference across the front of 1.2. This gives a predicted depth to the foot of the front of $130 \mathrm{~m}$, compared to an observed mean depth of $125 \mathrm{~m}$. This is one of the first observational verifications of the relationship between frontal position and jet transport. It should be noted that because the position of the foot of the front can be defined in a number of different ways and the choice of bounds for the density difference across the front is open to interpretation, these results are not precise. The observed depth of the foot of the front is accurate to within approximately $\pm 10 \mathrm{~m}$. The front over which the density difference is calculated could be defined more narrowly or broadly, resulting in $\Delta \rho$ ranging from approximately 0.8 to 1.4. Over these ranges the mean $h_{b}$ is $122-160 \mathrm{~m}$, with larger $\Delta \rho$ corresponding to smaller values of $h_{b}$. The actual mean depth of the foot of the front, with uncertainty, is approximately $115-135 \mathrm{~m}$.

[44] Figure 13 shows the general relationship between density difference across the shelfbreak front and jet transport. This relationship also works well for the climatology of the nearby New Jersey shelf, with mean transport of

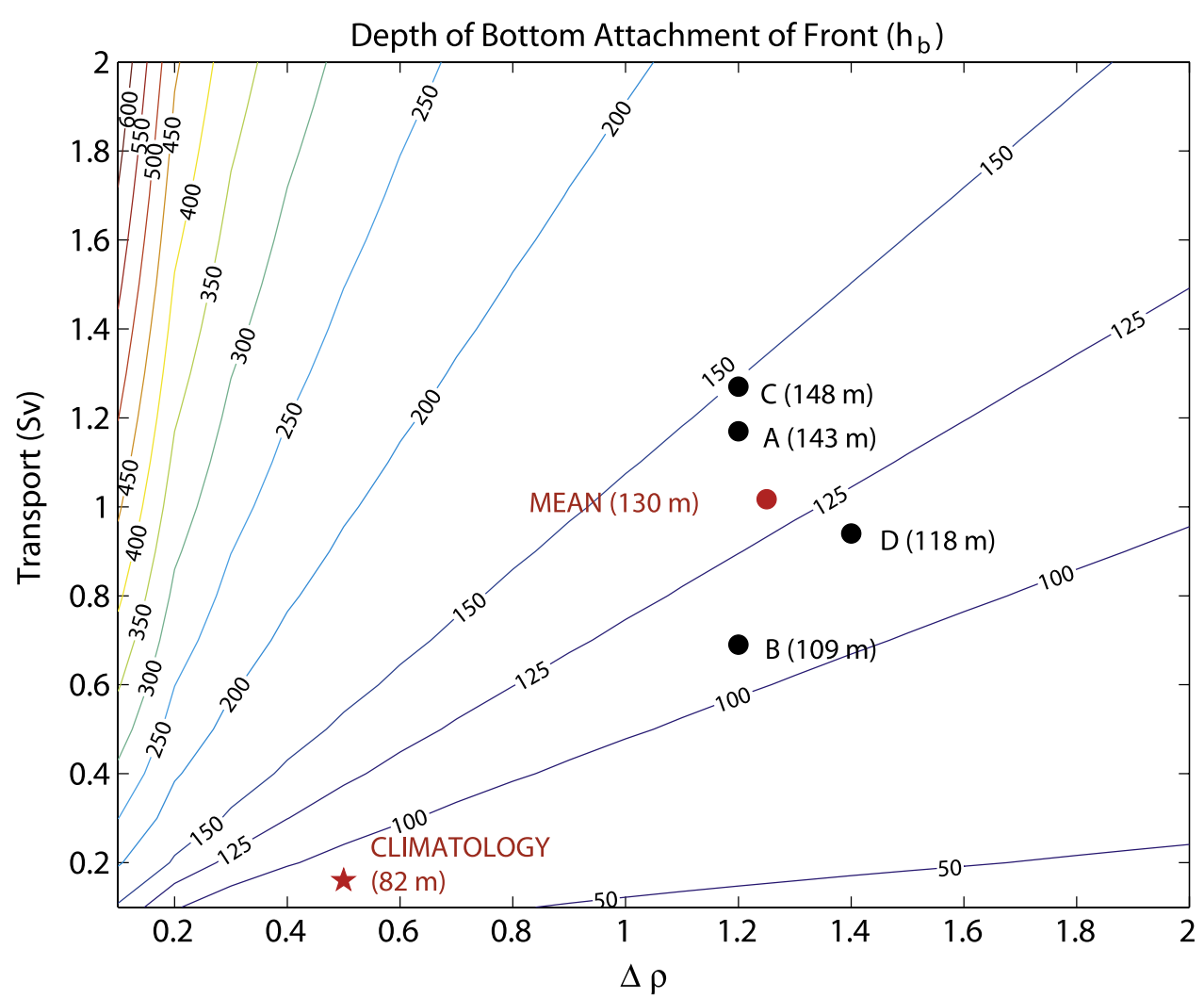

Figure 13. Contours of shelfbreak front bottom attachment depth, as predicted by the Yankovsky and Chapman [1997] model as a function of shelf transport and density gradient. Points are plotted for the calculated bottom attachment depth for each of the four sections surveyed, plus their mean, as well as for the climatology [Linder and Gawarkiewicz, 1998]. Actual bottom attachment depths (as given in Table 3) are A, $134 \mathrm{~m}$; B, $126 \mathrm{~m}$; C, $120 \mathrm{~m}$; D, $120 \mathrm{~m}$; mean, $125 \mathrm{~m}$; and climatology, $75 \mathrm{~m}$. 
$0.16 \mathrm{~Sv}$ and a density difference of 0.5 (based on a very limited number of data sets). The mean depth to the foot of the front is $75 \mathrm{~m}$, compared to $82 \mathrm{~m}$ predicted by the Yankovsky and Chapman [1997] theory.

[45] The thermohaline structure at the front is theoretically consistent with the large-volume transport measured during the survey. It is unclear whether hydrographic conditions during this survey are representative of this time period, or if they are anomalous. However, a number of other studies in the Mid-Atlantic Bight have seen slope water intrusions during the fall. During the Nantucket Shoals Flux Experiment [Beardsley et al., 1985], water over the mid-shelf in November and December had higher than normal salinity and was the warmest of the time series. The climatology for the northern Mid-Atlantic Bight also shows that the salinity front is at its most shoreward position during October-November; however, the foot of the front is also at its most shoreward and shallowest position.

[46] Earlier studies have also seen transport on the order of $1 \mathrm{~Sv}$ in the Mid-Atlantic Bight [Voorhis et al., 1976; Burrage and Garvine, 1988; Schlitz et al., 2001], while others are in the range of 0.2-0.4 Sv [Beardsley et al., 1985; Ramp et al., 1988; Biscaye et al., 1994]. It is interesting to note that most of the former, including this study, are based on geostrophic velocity calculated from hydrographic sections, while the latter are all based on moored current observations. While moored time series observations might appear more reliable in some respects, in that they can give us more than a short-term snapshot, they are more subject to transport errors from resolution problems. If moorings are not spaced closely enough to resolve the jet (which is itself often meandering), much of the high current activity will be missed. For example, the Biscaye et al. [1994] transport is based on current measurements from three SEEP II moorings spaced at $25-$ to $30-\mathrm{km}$ intervals between the $60-\mathrm{m}$ and $130-\mathrm{m}$ isobaths. The more spatially resolved NSFE transport estimate is based on current measurements from five moorings with approximately $20-\mathrm{km}$ spacing between the $25-\mathrm{m}$ and $200-\mathrm{m}$ isobaths, and one with surface currents only at the $1000-\mathrm{m}$ isobath. With mean jet widths of $21 \mathrm{~km}$ [Linder and Gawarkiewicz, 1998] and jet cores of $\leq 10 \mathrm{~km}$, a major portion of the transport may not be resolved by current meters at $20-$ to $30-\mathrm{km}$ intervals. The moorings in the Schlitz et al. [2001] study were placed at the 60-, 100-, and 320-m isobaths and had cross-shelf spacing of 40 and $20 \mathrm{~km}$. However, the velocity data clearly show the presence of the shelfbreak jet at the 100-m mooring, with velocities of up to $50 \mathrm{~cm} / \mathrm{s}$, and a mean surface velocity of $27 \mathrm{~cm} / \mathrm{s}$.

[47] If higher transport estimates for the Mid-Atlantic Bight are accurate, this would significantly affect transport budgets for the northeastern North American coast. Present estimates [Loder et al., 1998] for large-scale coastal transport are based on regional transport estimates for seven zones from the Labrador Shelf to Cape Hatteras. Differences between upstream and downstream zones are balanced by cross-shelf export (a "leaky current" model). The NSFE transport estimate $(0.38 \mathrm{~Sv})$ is used in this budget for the Mid-Atlantic Bight zone. Substituting one of the higher estimates for MAB transport, 1-2 Sv, significantly alters the balance between alongshore transport and cross-shelf export. It also calls into question the upstream transport estimate of $0.6 \mathrm{~Sv}$ for the Halifax section. Loder et al. [1998] note that the low implied salinity for export between Halifax and Nantucket shoals "probably reflects an inadequate estimate of along-shelf transport," and that an additional $0.5 \mathrm{~Sv}$ across the Halifax section into the Mid-Atlantic Bight would make the implied export salinity more reasonable (32.9). This would bring the net transport into the MAB to over $1 \mathrm{~Sv}$, and requires either greater transport inputs from upstream sources, or lower crossshelf export (a less leaky current).

[48] Little concrete evidence exists for the inferred crossshelf export of large quantities of shelf water. In light of the lack of data suggesting direct cross-shelf transport, and with increasing evidence of high alongshelf transport, it is possible that a model such as the slope-sea gyre of Csanady and Hamilton [1988], with limited direct cross-shelf exchange, may be more applicable. In this model, dominant circulation is southwestward along coastal isobaths, and northeastward along the Gulf Stream, with MAB shelf water entering Gulf Stream circulation near Cape Hatteras, and Gulf Stream water re-entering the slope in the northern MidAtlantic Bight, primarily through the effects of warm-core rings and streamers ejected from Gulf Stream meanders. Radiochemical tracer evidence conducted concurrently with this and other cross-shelf surveys of the region so far shows no signs of cross-shelf export of surface shelf water on timescales of weeks to months, but does support the Gulf Stream recirculation pathway, as do several drifter studies [Hare et al., 2002; Dragos et al., 1998]. This area of inquiry, identified in the Loder et al. [1998] review as being one of the "key research issues" in the region, still has many unanswered questions.

[49] Acknowledgments. The authors gratefully acknowledge support from the Duke University-University of North Carolina Oceanographic Consortium for ship time aboard the R/V Cape Hatteras. Thanks are extended to the captain and crew of the R/V Cape Hatteras for exceptional assistance during our cruise. Doctoral field research was made possible through the WHOI Ocean Ventures Fund. M. S. L. also gratefully acknowledges support from the Office of Naval Research (N00014-01-1-0260).

\section{References}

Bane, J. M., O. Brown, R. Evans, and P. Hamilton (1988), Gulf Stream remote forcing of shelfbreak currents in the Mid-Atlantic Bight, Geophys. Res. Lett., 15(5), 405-407.

Beardsley, R. W. Boicourt, and D. Hansen (1976), Physical oceanography of the Middle Atlantic Bight, Limnol. Oceanogr., 2, Spec. Symp., 20-34. Beardsley, R., D. Chapman, K. Brink, S. Ramp, and R. Schlitz (1985), The Nantucket Shoals Flux Experiment: I. A basic description of the current and temperature variability, J. Phys. Oceanogr., 15, 713-748.

Biscaye, P. E., C. Flagg, and P. Falkowski (1994), The Shelf Edge Exchange Process experiment, SEEP II: An introduction to hypotheses, results and conclusions, Deep Sea Res., Part II, 41, 231-252.

Burrage, D., and R. Garvine (1988), Summertime hydrography at the shelfbreak front in the Middle Atlantic Bight, J. Phys. Oceanogr., 18, 13091319.

Churchill, J. H., and P. C. Cornillon (1991), Gulf Stream water on the shelf and upper slope north of Cape Hatteras, Cont. Shelf Res., 11(5), 409431

Churchill, J. H., E. R. Levine, D. N. Connors, and P. C. Cornillon (1993), Mixing of shelf, slope and Gulf Stream water over the continental slope of the Middle Atlantic Bight, Deep Sea Res., Part I, 40, $1063-1085$.

Csanady, G. T., and P. Hamilton (1988), Circulation of slopewater, Cont. Shelf Res., 8(5-7), 565-624.

Dragos, P., F. Aikman III, and D. Redford (1998), Lagrangian statistics and kinematics from drifter observations pertaining to dispersion of sludge from the 106-mile site, J. Mar. Environ. Eng., 2, 21-41. 
Drinkwater, K. F., R. A. Myers, R. G. Pettipas, and T. L. Wright (1994), Climatic data for the Northwest Atlantic: The position of the shelf/ slope front and the northern boundary of the Gulf Stream between $50^{\circ} \mathrm{W}$ and $75^{\circ} \mathrm{W}, 1973-1992$, Can. Data Rep. Fish. Oceans Sci., 125, $103 \mathrm{pp}$

Flagg, C., and R. Beardsley (1978), On the stability of the shelf water/ slope water front south of New England, J. Geophys. Res., 83(9), $4623-4630$.

Fong, D. A. (1998), Dynamics of freshwater plumes: Observations and numerical modeling of the wind-forced response and alongshore freshwater transport, Ph.D. thesis, Mass. Inst. of Technol./Woods Hole Oceanogr. Inst., Woods Hole.

Fratantoni, P. S., R. S. Pickart, D. J. Torres, and A. Scotti (2001), Mean structure and dynamics of the shelfbreak jet in the Middle Atlantic Bight during fall and winter, J. Phys. Oceanogr., 31, 2135-2156.

Gawarkiewicz, G., T. Ferdelman, T. Church, and G. Luther III (1996) Shelfbreak frontal structure on the continental shelf north of Cape Hatteras, Cont. Shelf Res., 16, 1751-1773.

Gawarkiewicz, G., K. Brink, F. Bahr, R. Beardsley, M. Caruso, J. Lynch, and C.-S. Chiu (2004), A large amplitude meander of the shelfbreak front in the Middle Atlantic Bight: Observations from the Shelfbreak PRIMER Experiment, J. Geophys. Res., 109, C03006, doi:10.1029/2002JC001468.

Hare, J. A., J. H. Churchill, R. Cowen, T. J. Berger, P. C. Cornillon, P. Dragos, S. M. Glenn, J. J. Govoni, and T. N. Lee (2002), Routes and rates of larval fish transport from the southeastern to the northeastern United States continental shelf, Limnol. Oceanogr., 47, 1774-1789.

Houghton, R. W., and J. Marra (1983), Physical/biological structure and exchange across the thermohaline shelf/slope front in the New York Bight, J. Geophys. Res., 88(C7), 4467-4481.

Houghton, R. W., R. Schlitz, R. C. Beardsley, B. Butman, and J. L. Chamberlain (1982), The Middle Atlantic Bight cold pool: Evolution of the temperature structure during summer 1979, J. Phys. Oceanogr., $12,1019-1029$.

Lentz, S. (2003), A climatology of salty intrusions over the continental shelf from Georges Bank to Cape Hatteras, J. Geophys. Res. 108(C10), 3326, doi:10.1029/2003JC001859.

Lentz, S., K. Shearman, S. Anderson, A. Plueddemann, and J. Edson (2003), Evolution of stratification over the New England shelf during the Coastal Mixing and Optics study, August 1996-June 1997, J. Geophys. Res., 108(C1), 3008, doi:10.1029/2001JC001121.

Linder, C. A. (1996), A climatology of the Middle Atlantic Bight shelfbreak front, Master's thesis, Mass. Inst. of Technol./Woods Hole Oceanogr. Inst., Woods Hole.
Linder, C., and G. Gawarkiewicz (1998), A climatology of the shelfbreak front in the Middle Atlantic Bight, J. Geophys. Res., 103(C9), 18,40518,423 .

Loder, J., B. Petrie, and G. Gawrkiewicz (1998), The coastal ocean off northeastern North America: A large scale view, in The Sea, vol. 11, edited by A. Robinson and K. Brink, chap. 5., pp. 105-133, John Wiley, Hoboken, N. J.

Lozier, M. S., M. S. C. Reed, and G. Gawarkiewicz (2002), Instability of a shelfbreak front, J. Phys. Oceanogr., 32, 924-944.

Moody, J. A., et al. (1984), Atlas of tidal elevation and current observations on the northeast American continental shelf and slope, Bull. 1611, 100 pp., U. S. Geol. Surv., Washington, D. C.

Page, F., R. Losier, K. Drinkwater, B. Petrie, G. Harrison, and D. Sameoto (2001), Overview of physical and biological oceanographic conditions on Georges Bank, technical report, Can. Sci. Adv. Secr., Fish. and Oceans Sci., Ottawa.

Ramp, S. R., W. S. Brown, and R. C. Beardsley (1988), The Nantucket Shoals Flux Experiment 3: The alongshelf transport of volume, heat, salt and nitrogen, J. Geophys. Res., 93(C11), 14,039-14,054.

Savidge, D., and J. Bane (2001), Wind and Gulf Stream influences on along-shelf transport and off-shelf export at Cape Hatteras, North Carolina, J. Geophys. Res., 106(C6), 11,505-11,527.

Schlitz, R., J. P. Manning, and K. W. Smith (2001), Structure and transport of alongshelf currents across the southern flank of Georges Bank during late summer, 1982, Deep Sea Res., Part II, 48, 341-372.

Ullman, D., and P. Cornillon (1999), Satellite-derived sea surface temperature fronts on the continental shelf off the northeast U.S. coast, J. Geophys. Res., 104(C10), 23,459-23,478.

Voorhis, A. D., D. Webb, and R. C. Millard (1976), Current structure and mixing in the shelf/slope waterfront south of New England, J. Geophys. Res., 81(21), 3695-3708.

Yankovsky, A., and D. Chapman (1997), A simple theory for the fate of buoyant coastal discharges, J. Phys. Oceanogr., 27, 1386-1401.

G. G. Gawarkiewicz and W. B. Owens, Woods Hole Oceanographic Institution, MS 21, Woods Hole, MA 02543, USA.

M. S. Lozier, Earth and Ocean Sciences, Duke University, Durham, NC 27708, USA.

L. L. Rasmussen, Scripps Institution of Oceanography, University of California, San Diego, 9500 Gilman Drive, San Diego, CA 92093-0218, USA. (raz@coast.ucsd.edu) 